\title{
Functional descriptions of feeding and energetics of the Pacific oyster Crassostrea gigas in New Zealand
}

\author{
Jeffrey S. Ren ${ }^{1, *}$, Alex H. Ross ${ }^{2}$, David R. Schiel ${ }^{3}$ \\ ${ }^{1}$ Centre of Excellence in Marine Ecology and Aquaculture, PO Box 8602, Christchurch, New Zealand \\ ${ }^{2}$ National Institute of Water and Atmospheric Research, PO Box 8602, Christchurch, New Zealand \\ ${ }^{3}$ Department of Zoology, University of Canterbury, Private Bag 4800, Christchurch, New Zealand
}

\begin{abstract}
Pacific oysters Crassostrea gigas were fed a mixed diet of algae and silt over a range of concentrations from 0.8 to $637 \mathrm{mg} \mathrm{l}^{-1}$, and an organic content ranging from 0.7 to $72 \%$. These data were used to parameterise a set of functions describing the physiological response of oysters to varying environmental conditions. All parameters were standardised to body length. There was greater variation of size-specific clearance rate (CR) standardised to dry tissue weight than to length. CR increased hyperbolically with temperature with a maximum rate $\left(0.24 \mathrm{l} \mathrm{h}^{-1} \mathrm{~cm}^{-1}\right)$ at $20.7^{\circ} \mathrm{C}$. Most feeding experiments were carried out at 10 to $13^{\circ} \mathrm{C}$, except for the measurements of temperature effect. CR increased rapidly with increasing seston concentration, peaked at about $10 \mathrm{mg} \mathrm{l}^{-1}$, above which it consistently decreased. It was modelled as a function of pumping rate of water and extraction efficiency of particles from water. The filtration rate was found to be a Type 2 hyperbolic function of seston concentration within the range tested. Ingestion rate was described as a function of food quantity, quality and selective ingestion of organic particles. A positive effect of organic content on absorption efficiency was found only at a very low organic content of less than $5 \%$, while above this level, absorption efficiency was constant at $86 \%$. Oxygen consumption rate had an allometric relationship to body size and increased over the range of experimental temperatures.
\end{abstract}

KEY WORDS: Pacific oyster · Clearance $\cdot$ Ingestion $\cdot$ Absorption $\cdot$ Oxygen consumption

\section{INTRODUCTION}

The Pacific oyster Crassostrea gigas was introduced accidentally into New Zealand around the late 1960s (Dinamani 1971). The subsequent success of the species has resulted in its gradual replacement of the native rock oyster Saccostrea commercialis as the preferred-farmed species (Dinamani 1987). There is a perception amongst oyster farmers that growth rates have declined and mortality rates increased as a consequence of the increasing intensity of farming. Such declines have been observed elsewhere as a conse-

*E-mail: j.ren@niwa.cri.nz quence of increased stock density (Héral 1993). Management plans have been proposed to regulate the cultivated biomass to fit within the carrying capacity of the different ecosystems (Héral \& Drinkward 1990, Héral \& Deslous-Paoli 1991). Ecophysiological models, based on the physiological responses of animals to changes in environmental conditions, have been widely used as a tool for the management of shellfish culture (Klepper et al. 1994). Such models are used to simulate the processes of energy acquisition and expenditure. The quality of these simulations is partly dependent on the accuracy and validity of the functional descriptions of processes such as filtration, ingestion and metabolic rates. Hence it is important to base these functional descriptions on consistent and systematic datasets col- 
lected over the range of biotic and abiotic conditions experienced by the farmed population.

Many studies on the physiology of Pacific oysters have been carried out (e.g. Neudecker 1981, Gerdes 1983a,b, Deslous-Paoli et al. 1992, Barillé et al. 1994, 1997, Bougrier et al. 1995). However, the feeding and metabolic rates show large differences among the studies. For example, the clearance rate for Crassostrea gigas was found to be constant at $2.2 \mathrm{l} \mathrm{h}^{-1} \mathrm{~g}^{-1}$ by Barillé et al. (1994), $4.8 \mathrm{l} \mathrm{h}^{-1} \mathrm{~g}^{-1}$ by Bougrier et al. (1995) and $2.75 \mathrm{l} \mathrm{h}^{-1} \mathrm{~g}^{-1}$ by Gerdes (1983a). Oxygen consumption rates at $20^{\circ} \mathrm{C}$ were determined to be 0.65 and $0.96 \mathrm{ml} \mathrm{O}_{2} \mathrm{~h}^{-1} \mathrm{~g}^{-1}$ by Gerdes (1983b) and Bougrier et al. (1995), respectively. This variation in physiological rates obtained by different authors may have been due to experimental artefacts or to genetic differences within the species.

Environmental conditions in New Zealand differ from those in many other oysters farming areas of the world. For example, the water temperature is relatively low (approx. 8 to $25^{\circ} \mathrm{C}$ ) with a small range of variation (typically $10^{\circ} \mathrm{C}$ ), chlorophyll a concentration varies from 0.2 to $6 \mu^{-1} \mathrm{~g}^{-1}$ (Gibbs \& Vant 1997), and seston concentration from 5 to $15 \mathrm{mg} \mathrm{l}^{-1}$ (Ross unpubl. data) over a year. Although the physiological response of $C$. gigas has been studied by a number of authors (e.g. Neudecker 1981, Gerdes 1983a,b, Barillé et al. 1997) in other parts of the world, only 1 such study, limited to reproduction, has been carried out in New Zealand (Dinamani 1987). The physiology of Pacific oysters in New Zealand waters is hence poorly understood, but is crucial to the prudent management of an expanding oyster-farming industry.

The present study aimed to determine how filtration, ingestion, absorption and respiration are affected in oysters held under different environmental conditions. The measurements provide a set of relationships for which the physiological rates can be expressed as functions of environmental variation. We first developed a dynamic energy budget (DEB) model to simulate the growth of Crassostrea gigas in varying environmental conditions (Ren \& Ross unpubl. data). In order to provide important physiological information and accurate parameters for that model, here we measured the feeding behaviour and physiological processes in C. gigas over a wide range of food quantity and quality. Physiological measurements are described in terms of mathematical equations based on sound physiological principles.

\section{MATERIALS AND METHODS}

Treatments of oysters and experimental design. Oysters ranging from 1.9 to $15.0 \mathrm{~cm}$ shell length $(1.5$ to $125 \mathrm{ml}$ in volume) were collected from an oyster farm in the Marlborough Sounds, New Zealand $\left(173^{\circ} 42^{\prime}-46^{\prime} \mathrm{E}, \quad 41^{\circ} 02^{\prime}-05^{\prime} \mathrm{S}\right)$, in April 1998. The oysters were cleaned of epibionts and immediately transported to University of Canterbury Field Station in Kaikoura ( $3 \mathrm{~h}$ by road) where they were kept in running seawater and acclimatised for 2 mo prior to experiments. Before each experiment, length, total wet weight and total body volume were measured to the nearest $\mathrm{mm}, \mathrm{g}$, and $\mathrm{ml}$. After each set of experiments, the same oysters were kept in running seawater for the next measurements in the experiments unless otherwise specified. Once the physiological measurements were complete, the soft tissue from each oyster was excised, dried at $60^{\circ} \mathrm{C}$ for $72 \mathrm{~h}$ and weighed, ashed at $500^{\circ} \mathrm{C}$ for $4 \mathrm{~h}$ and weighed for ash-free dry weight.

Different sizes of oysters were used only for the purpose of measurements of size effect on physiological rates. For all other physiological measurements, 10 oysters with similar size (95 $\pm 5 \mathrm{~mm}$ in length) were used and each was placed in one of the chambers described below.

Two rigid trays each containing 6 perspex chambers were used for the feeding experiments. The first tray contained chambers of dimensions $10 \times 10 \times 8 \mathrm{~cm}$ and the other tray contained larger chambers of size $20 \times$ $10 \times 10 \mathrm{~cm}$. Oysters were placed into 10 chambers whilst the other 2 chambers were left empty as controls. Oysters were left undisturbed for $1 \mathrm{~h}$ prior to the start of measurements and each measurement lasted for $3 \mathrm{~h}$. The flow rate through each chamber was adjusted in the range 150 to $300 \mathrm{ml} \mathrm{min}{ }^{-1}$ (calculated over the duration of the experiment) to ensure a significant difference of particle concentrations between outflow and inflow, as represented by the control chambers, and to avoid the possibility of re-circulation of water through the mantle cavity of the oysters. To minimise temporal variation in clearance rates of oysters, 12 tanks ( 1 for each chamber) were used to collect outflow. Therefore, outflow from each chamber was all collected during a $3 \mathrm{~h}$ trial and well mixed at the end of a trial before water samples were taken.

For the measurement of the temperature effect on clearance and oxygen consumption rates, a $500 \mathrm{ltank}$ was designed with cooling and heating systems controlled by a thermostat for required temperatures. Oysters were acclimatised in the system to the following temperatures: $10,12,15,19,22,25,27$ and $29^{\circ} \mathrm{C}$. In addition to $50 \mathrm{l} \mathrm{h}^{-1}$ of natural seawater passing through the temperature control tank, approximately $1 \times 10^{9}$ cells of the alga Pavlova luthori were added each day per oyster to ensure a sufficient food supply. The oysters were thus acclimatised for 12 to $15 \mathrm{~d}$ to each experimental temperature before each experiment was conducted. Particle and chlorophyll a consump- 
tion of 10 oysters was measured through the above feeding chambers to calculate clearance rates; 3 replicates were made for each temperature. There were no considerable variations in other environmental variables, since there was little variation in the natural seawater, e.g. in chlorophyll a (chl, $\left.1.5 \pm 0.3 \mu \mathrm{g} \mathrm{l}^{-1}\right)$, particulate organic matter $\left(\mathrm{POM}, 0.8 \pm 0.3 \mathrm{mg} \mathrm{l}^{-1}\right.$ ) and total particulate matter (TPM, $5.9 \pm 1.1 \mathrm{mg} \mathrm{l}^{-1}$ ).

During measurements of size effect on clearance rates, the temperature varied between 10 and $13^{\circ} \mathrm{C}$ and there was no great variation of other environmental variables throughout these experiments (chl: $0.8 \pm$ $0.2 \mu \mathrm{g} \mathrm{l}^{-1}$, POM: $1.6 \pm 0.3 \mathrm{mg} \mathrm{l}^{-1}$, TPM: $15.5 \pm 1.2 \mathrm{mg}$ $\mathrm{l}^{-1}$ ). One large oyster was placed into each of the large chambers and a number of small oysters were placed into each of the small chambers. Clearance rates, involving multiple small oysters, were calculated from total records. A wide size range of oysters (19 to $145 \mathrm{~mm}$ in length) was used in the experiment. The clearance rate of all size groups could not be measured for 1 trial due to limitation of chambers. Therefore, we conducted 3 trials and 6 replicates in each trial. The number of oysters in a feeding chamber used for these measurements are listed in Table 1.

For measurements of physiological response of oysters to a wide range of food quality and quantity, natural seawater was pumped into a 201 header tank before passing through raceways into the 12 chambers to ensure a constant flow. A stock solution of algae and silt in another $20 \mathrm{l}$ tank was pumped by a peristaltic pump at the required rate via $3 \mathrm{~mm}$ diameter tubing into a plastic buffer at the front of the chambers. This was done to ensure adequate mixing of the stock suspension with the raw seawater before entering the chambers. Particle and chlorophyll a consumption were measured using 10 similarly sized oysters $(95 \pm$ $5 \mathrm{~mm}$ in length) for each dietary condition at a water temperature of $12 \pm 1^{\circ} \mathrm{C}$. Different kinds of particle concentrations were passed to the feeding chambers. A range of different food quality and seston concentrations was produced by adding the alga Pavlova luthori (4 to $6 \mu \mathrm{m}$ ) and surficial sediments (4 to $50 \mu \mathrm{m}$ ) to

Table 1. Crassostrea gigas. Oysters used for experiments of size effect on clearance rate

\begin{tabular}{|ccc|}
\hline Mean length $(\mathrm{mm})$ & SD & No. of oysters \\
\hline 19 & 0.9 & 7 \\
23 & 1.2 & 6 \\
33 & 1.4 & 6 \\
38 & 1.0 & 6 \\
43 & 1.2 & 6 \\
47 & 1.6 & 4 \\
55 & 2.3 & 2 \\
$>60$ & - & 1 \\
\hline
\end{tabular}

natural seawater. The stock solution was stored in a 201 tank and pumped to the chambers as mentioned above. Algae culture was obtained from the NIWA Aquaculture laboratory at Mahanga Bay. Surficial sediment was collected from a mudflat in Kaikoura and was sieved through a $50 \mu \mathrm{m}$ Nitex screen. It was then combusted at $500^{\circ} \mathrm{C}$ for $8 \mathrm{~h}$ to remove organic matter. For the low seston concentration treatment, natural seawater was diluted with $1 \mu \mathrm{m}$ filtered seawater. The filtered seawater was stored in a storage tank. The ratio of natural and filtered seawater was worked out according to the required particle composition. The natural and filtered seawater was mixed in a $650 \mathrm{l}$ tank before being pumped to the 201 header tank. Outflow from each chamber was individually collected and mixed during each $3 \mathrm{~h}$ feeding trial (see above), which minimised temporal variation of clearance rates of oysters. Therefore, 1 trial was conducted for each dietary condition.

Variation of physiological rates with the condition of animals has been reported for other marine bivalves (e.g. Iglesias et al. 1996, Labarta et al. 1997). To investigate whether this variation exists in Crassostrea gigas, we measured clearance rate in both spring, when oysters had a high condition index, and in winter, when their condition index was low. Oysters were acclimatised to a water temperature of $17 \pm 0.5^{\circ} \mathrm{C}$ for $2 \mathrm{wk}$ in both seasons before experiments were conducted. Chl, POM and TPM, were respectively: $1.5 \pm$ $0.2 \mu \mathrm{g} \mathrm{l}^{-1}, 0.7 \pm 0.3$ and $5.6 \pm 0.4 \mathrm{mg} \mathrm{l}^{-1}$ in spring, and $1.2 \pm 0.4 \mu \mathrm{g} \mathrm{l}^{-1}, 0.6 \pm 0.3$ and $7.0 \pm 0.6 \mathrm{mg} \mathrm{l}^{-1}$ in winter. We chose 4 size groups of oysters $(85 \pm 2,95 \pm 2,100 \pm$ 2 and $110 \pm 2 \mathrm{~mm}$ in length) in both seasons. Unlike for the other measurements, the oysters were excised immediately after these measurements in each season to obtain dry tissue weight of individuals. Condition index (CI) was calculated by

$$
\mathrm{CI}=100 \times \mathrm{DTW} / \mathrm{DSW}
$$

where DTW is dry tissue weight $(\mathrm{g})$ and DSW is dry shell weight $(\mathrm{g})$. CI was higher in spring $(\mathrm{CI}=8.1 \pm 1.3$, $\mathrm{n}=20)$ than in winter $(\mathrm{CI}=5.0 \pm 1.1, \mathrm{n}=20)$. Clearance rates were standardised to both DTW and length in both seasons, following standardisation procedures.

Water sampling and measurements: Outflow collected in each tank, representing each chamber was well mixed at the end of a trial. At least 11 of water was sampled from each tank representing the outflow of each 'control' or 'oyster' chamber. Of each water sample, $500 \mathrm{ml}$ was filtered onto ashed and pre-weighed $25 \mathrm{~mm}$ diameter GF/F filters ( $0.7 \mu \mathrm{m}$ pore, Whatman). The filters were then dried in an oven at $105^{\circ} \mathrm{C}$ for $48 \mathrm{~h}$, weighed and ashed in a muffle furnace at $500^{\circ} \mathrm{C}$ for $4 \mathrm{~h}$. This method allowed both TPM ( $\left.\mathrm{mg} \mathrm{l}^{-1}\right)$ and particulate inorganic matter (PIM) $\left(\mathrm{mg} \mathrm{l}^{-1}\right)$ to be measured. 
POM (mg l-1) concentration was calculated by subtracting PIM from TPM. The organic content was computed (POM:TPM ratio) as an indicator of food quality.

For the measurement of chlorophyll $a$, a further $500 \mathrm{ml}$ of seawater from each sample was filtered through $25 \mathrm{~mm}$ Whatman GF/F filters. The filters were placed into plastic envelopes and stored in a dark box at $-20^{\circ} \mathrm{C}$ until analysis. The chlorophyll a concentration was measured according to standard procedures using acetone extraction and fluorometric analysis (Strickland \& Parson 1968). In addition to estimating CR from reduction in chlorophyll $a$, it was also calculated from reduction in particle numbers for the purpose of comparison. For some samples, $15 \mathrm{ml}$ of the water sample was analysed using a Coulter Counter (Model ZM and tube with $100 \mu \mathrm{m}$ orifice diameter) to measure the total count of particles larger than $3 \mu \mathrm{m}$ equivalent spherical diameter in both inflow and outflow.

Since 10 chambers each contained a similarly sized oyster, 10 samples were obtained and therefore each trial was equivalent to 10 replicates.

Clearance rate: Clearance rate $\left(\mathrm{CR}_{;} \mathrm{l} \mathrm{h}^{-1}\right)$ was estimated by measuring particle and chlorophyll a consumptions

$$
\mathrm{CR}=\left(\frac{C_{\text {control }}-C_{\mathrm{i}}}{C_{\text {control }}}\right) \times V
$$

where $C_{\mathrm{i}}=$ particle $\left(\right.$ no. $\left.\mathrm{l}^{-1}\right)$ or chlorophyll a $\left(\mu \mathrm{g} \mathrm{\textrm {l } ^ { - 1 } )}\right.$ concentration of outflow from chambers containing oysters, $C_{\text {control }}=$ particle or chlorophyll a concentration of outflow from control chambers, and $V=$ water flow rate $\left(\mathrm{l} \mathrm{h}^{-1}\right)$.

Filtration, biodeposition, and ingestion: Filtration rates of POM and TPM were calculated as the products of $\mathrm{CR}$ and POM and TPM concentrations, as

$$
\mathrm{FR}_{\mathrm{POM} / \mathrm{TPM}}=P_{\mathrm{POM} / \mathrm{TPM}} \times \mathrm{CR}
$$

where $\mathrm{FR}_{\mathrm{POM} / \mathrm{TPM}}$ is the filtration rate of POM $\left(\mathrm{mg} \mathrm{h}^{-1}\right)$ and TPM $\left(\mathrm{mg} \mathrm{h}^{-1}\right)$, respectively, and $P_{\mathrm{POM} / \mathrm{TPM}}$ is the particulate concentration of POM $\left(\mathrm{mg} \mathrm{l}^{-1}\right)$ and TPM $\left(\mathrm{mg} \mathrm{l}^{-1}\right)$, respectively.

Pseudofaeces were ejected from the inhalant siphon and deposited in a separate stream from the faeces. Faeces and pseudofaeces produced by individual oysters were collected from each chamber at the end of the experiment using a micro-pipette. Each sample was then filtered through a GF/F filter and treated as described above for determination of seston concentration.

Ingestion rate was estimated from the composition of the experimental diet and egestion rate of organic matter according to the formula

$$
\mathrm{IR}=\mathrm{CR} \times P_{\mathrm{POM}}-\mathrm{PF}_{\mathrm{o}}
$$

where IR $\left(\mathrm{mg} \mathrm{h}^{-1}\right)$ is ingestion rate of POM, $P_{\mathrm{POM}}$ is $\mathrm{POM}$ concentration in control chambers, and $\mathrm{PF}_{\mathrm{o}}(\mathrm{mg}$ $\mathrm{h}^{-1}$ ) is the rate of pseudofaeces production (organic component).

Absorption efficiency: Absorption efficiency (AE) was calculated as the product of organic ingestion and egestion, as

$$
\mathrm{AE}=\frac{\mathrm{IR}-O_{\mathrm{F}}}{\mathrm{IR}}
$$

where $O_{\mathrm{F}}$ is the faecal production rate of POM (mg $\left.\mathrm{h}^{-1}\right)$.

Oxygen consumption rate: The rate of oxygen consumption $\left(\mathrm{VO}_{2}: \mathrm{ml} \mathrm{O}_{2} \mathrm{~h}^{-1}\right)$ was measured in closed glass bottles of 500 to $1000 \mathrm{ml}$ capacity, depending on the size of oysters. Measurements of size effect on oxygen consumption rate were conducted using natural seawater (chl: $0.8 \pm 0.2 \mu \mathrm{g} \mathrm{l}^{-1}$, POM: $1.6 \pm 0.6 \mathrm{mg} \mathrm{l}^{-1}$ and TPM: $15.5 \pm 1.2 \mu \mathrm{g} \mathrm{l}^{-1}$ ) at a temperature of $17 \pm$ $0.3^{\circ} \mathrm{C}$. The size range of experimental oysters was 28 to $119 \mathrm{~mm}$ in length. Oxygen consumption rates were measured on 14 sizes of oysters. One large oyster or a number of small oysters was placed into the bottle immersed in seawater (Table 2). The average oxygen consumption rate of an individual was calculated from total records for multiple small oysters. However, measurements of temperature effect on oxygen consumption rate were conducted using 8 similarly sized oysters (95 $\pm 5 \mathrm{~mm}$ in length, 1 in each bottle) in each run. The effect of temperature on oxygen consumption was measured over a temperature range from 10 to $29^{\circ} \mathrm{C}$. Bottles contained seawater (chl: $1.5 \pm 0.3 \mu \mathrm{g} \mathrm{l}^{-1}, \mathrm{TPM}=$ $5.9 \pm 0.4 \mathrm{mg} \mathrm{l}^{-1}, \mathrm{POM}=0.7 \pm 0.1 \mathrm{mg} \mathrm{l}^{-1}$ ) without addition of seston and were immersed in the temperature control tank to keep temperature in the bottles the same as that in the tank.

One bottle without oysters was used as a control in each run. The water in the bottles was manually mixed using a syringe before sampling. One $\mathrm{ml}$ of the water sample was taken using a syringe at appropriate time intervals to obtain a representative rate. From each run, 6 to 8 samples were taken depending on oxygen concentration in the bottle. Oxygen tension was not allowed to decrease below $70 \%$ of air saturation to avoid depressing the effect on respiration rate (Prince 1995); 2 replicates were conducted for each measurement. Oxygen consumption rate was calculated as the

Table 2. Crassostrea gigas. Oysters used for experiments of size effect on oxygen consumption rate

\begin{tabular}{|ccc|}
\hline Mean length (mm) & SD & No. of oysters \\
\hline 28 & 1.6 & 6 \\
34 & 1.5 & 6 \\
52 & 1.8 & 6 \\
61 & 1.4 & 2 \\
$>70$ & - & 1 \\
\hline
\end{tabular}


rate of decrease of oxygen concentration inside the bottles as recorded by an oxygen meter (Radiometer, Model PHM 73).

Size standardisation of physiological rates. Physiological rates were standardised to those of an equivalent individual of $1 \mathrm{~cm}$ standard length or $1 \mathrm{~g}$ dry tissue weight, using the formula

$$
Y_{\mathrm{s}}=\left(1 / L_{\mathrm{e}}\right)^{d} \times Y_{\mathrm{e}}
$$

where $Y_{\mathrm{s}}$ represents the value for the standard individual, $Y_{\mathrm{e}}$ is the experimental value, and $L_{\mathrm{e}}$ is the experimental length or dry tissue weight. The allometric exponent $d=1.46$ and 2.36, respectively, was used for standardisation of $\mathrm{CR}$ and oxygen consumption rates to $1 \mathrm{~cm}$ standard length (see 'Results'); $d=0.44$ was used for CR to $1 \mathrm{~g}$ standard dry tissue weight (Bougrier et al. 1995).

Model structure. The main purpose of this study was to quantitatively describe the physiological response of oysters to varying environmental conditions. In doing so, we hoped to provide functional descriptions of physiological processes that could be incorporated into a DEB model. It is imperative therefore that these functions be based on sound physiological principles. Hence, rather than simply choosing functions which best describe the data, we have chosen functions which are most appropriate to the accepted understanding of the physiological process.

Influence of seston concentration on CR: The CR was measured as the removal rate of particles per unit volume. The CR is the product of the pumping rate of water and the extraction efficiency of particles from the water. It is difficult, in a practical sense, to disentangle the pumping rate from the extraction efficiency. We might expect that the CR saturates with increasing seston concentration. In fact, most published studies have observed a decline in CR as seston increases. This indicates that either there is a decline in the extraction efficiency with increasing seston concentration, or there is a decline in the pumping rate. The key to disentangling these mechanisms is determining what happens to the filtration rate (FR). If FR declines consistently with the decline in $\mathrm{CR}$, then we argue that the observed decline in $\mathrm{CR}$ is a consequence of a decline in the efficiency of extraction of particles from the water. If however, FR does not decrease as CR decreases, then we argue that the decline in $\mathrm{CR}$ is a consequence of a decline in the pumping rate, i.e. the extraction efficiency appears to remain constant because the flux of particles passing through the filtering apparatus remains constant. Although most published studies have found a decline in FR with increasing seston concentrations (e.g. Deslous-Paoli et al. 1987, Barillé et al. 1997), our studies (see 'Results') show no such decline. Hence we assume that the de- cline in $\mathrm{CR}$ over the range of seston concentrations we have measured is a consequence of a decline in pumping rate.

Hence we propose a function that has 2 components. The first component is a saturating function of the seston concentration to represent the saturating effect of particles clogging the filtering apparatus. This term we describe as a simple Type 2 hyperbolic functional response. We represent the feedback signal between seston concentration and pumping rate as discussed above, as a simple exponential decline in pumping rate as the seston concentration increases. Therefore:

$$
\mathrm{CR}=\mathrm{CR}_{\max } \times \frac{S}{S+S_{\mathrm{HFC}}} \times \mathrm{e}^{-k \times S}
$$

where CR $\left(1 \mathrm{~h}^{-1} \mathrm{~cm}^{-1}\right)$ is $\mathrm{CR}$ of a standard $1 \mathrm{~cm}$ oyster, $\mathrm{CR}_{\text {max }}\left(\mathrm{l} \mathrm{h}^{-1} \mathrm{~cm}^{-1}\right)$ is the maximum $\mathrm{CR}$ for standard $1 \mathrm{~cm}$ oyster, $S\left(\mathrm{mg} \mathrm{l}^{-1}\right)$ is seston concentration, $S_{\mathrm{HFC}}\left(\mathrm{mg} \mathrm{l}^{-1}\right)$ is half the concentration at which maximum CR occurs and $k$ is the coefficient describing the change in pumping rate with increasing $S$.

Influence of temperature on CR: Based on previous information on various oyster species (e.g. Crisp et al. 1985, Le Gall \& Raillard 1988, Bougrier et al. 1995), CR was modelled as a hyperbolic function of temperature as:

$$
\mathrm{CR}=\mathrm{CR}_{\operatorname{maxl}}-\beta \times\left(T-T_{\mathrm{C}}\right)^{2}
$$

where $\mathrm{CR}_{\operatorname{maxl}}\left(\mathrm{l} \mathrm{h}^{-1} \mathrm{~cm}^{-1}\right)$ is the maximal CR of a standard $1 \mathrm{~cm}$ oyster, $\beta\left(\mathrm{h} \mathrm{h}^{-1} \mathrm{~cm}^{-1}{ }^{\circ} \mathrm{C}^{-2}\right)$ is a coefficient of temperature effect on $\mathrm{CR}, T\left({ }^{\circ} \mathrm{C}\right)$ is water temperature, and $T_{\mathrm{C}}\left({ }^{\circ} \mathrm{C}\right)$ is the optimum pumping temperature, at which the maximum CR would be expected to occur.

Filtration rate. The $F R$ is the product of the $C R$ and the $S$. As discussed above, if it is assumed that the pumping rate is regulated by the oyster in order to maintain a constant extraction rate of particles as the $S$ increases, then the FR saturates with increasing $S$. Hence we describe FR as a Type 2 function of $S$ :

$$
\mathrm{FR}=\mathrm{FR}_{\max } \times \frac{S}{S+S_{\mathrm{HFF}}}
$$

where FR $\left(\mathrm{mg} \mathrm{h}^{-1} \mathrm{~cm}^{-1}\right)$ is for a standard $1 \mathrm{~cm}$ oyster, $\mathrm{FR}_{\max }\left(\mathrm{mg} \mathrm{h}^{-1} \mathrm{~cm}^{-1}\right)$ is the maximum FR and $S_{\mathrm{HFF}}$ $\left(\mathrm{mg} \mathrm{l}^{-1}\right.$ ) is the half-saturation $S$ (half the concentration at which maximum filtration occurs).

Ingestion rate: There is overwhelming evidence that ingestion is a saturating function of $S$ for marine bivalves (e.g. Thompson \& Bayne 1974, Epifanio \& Edwart 1977, Crisp et al. 1985, Deslous-Paoli et al. 1992). This is partly due to the saturating nature of the FR as discussed above, but is also a consequence of increasing $S$ resulting only in greater pseudofaeces production (see Foster-Smith 1975, Barillé et al. 1997). Therefore we also describe IR as a Type 2 hyperbolic 
function of $S: S /\left(S+S_{\mathrm{HFI}}\right)$, with a different half-saturation constant to that used to describe the FR.

This above function gives us the total $S$ ingested. However, we are interested in the total IR of organic material; hence the IR of organics also depends on a function of the organic content of the seston (POM:S). In a case where there is no selectivity of material at the palps, the IR will simply be a function of the organic ratio times the ingested material. However, there is abundant evidence (e.g. Bayne \& Hawkins 1990, Deslous-Paoli et al. 1992, Iglesias et al. 1992, Barillé et al. 1997) that there is selection of organic material in preference to inorganic material at the palps. The sorting of organic material is efficient at low $S$ and inefficient or non-existent at high $S$ (e.g. Bayne \& Hawkins 1990, Navarro \& Widdows 1997). A simple function that describes this physiological behaviour is again a Type 2 functional response so that the ability of the oyster to sort material itself saturates with increasing $S$. Hence we describe the IR by the function:

$$
\mathrm{IR}=\mathrm{IR}_{\max } \times \frac{S}{S+S_{\mathrm{HFI}}} \times\left(\frac{\mathrm{POM}}{S}\right)^{\frac{S}{S+S_{\mathrm{HFS}}}}
$$

where IR $\left(\mathrm{mg} \mathrm{h}^{-1} \mathrm{~cm}^{-1}\right)$ is for a standard $1 \mathrm{~cm}$ oyster; $\mathrm{IR}_{\max }\left(\mathrm{mg} \mathrm{h}^{-1} \mathrm{~cm}^{-1}\right)$ is the maximum IR for a standard $1 \mathrm{~cm}$ oyster under the assumption that organic and inorganic material have identical density; POM (mg $\left.\mathrm{l}^{-1}\right)$ and $S\left(\mathrm{mg} \mathrm{l}^{-1}\right)$ are particulate organic matter and seston concentrations, respectively; $S_{\mathrm{HFI}}\left(\mathrm{mg} \mathrm{l}^{-1}\right)$ is half the seston concentration at which maximum ingestion rate occurs (for a given POM:S ratio); and $S_{\mathrm{HFS}}\left(\mathrm{mg} \mathrm{l}^{-1}\right)$ is half the seston concentration at which no selection occurs.

Absorption efficiency: We might expect that the absorption efficiency depends on the organic content of the seston. A relationship between the absorption efficiency and the organic content of ingested seston has been widely observed in marine bivalves (e.g. Bricelj \& Malof 1984, Bayne et al. 1987, Navarro \& Widdows 1997, Barillé et al. 1997) as the form:

$$
\mathrm{AE}=\mathrm{AE}_{\max } \times\left[1-\exp \left(-m \frac{\mathrm{POM}}{S}\right)\right]
$$

where $\mathrm{AE}_{\max }$ is the asymptote of $\mathrm{AE}$ and $m$ is a coefficient describing the change in $\mathrm{AE}$ with increasing organic content in the seston.

Influence of temperature on $\mathbf{V O}_{2}$ : Experiments have shown that $V \mathrm{O}_{2}$ strongly responds to increasing temperature for a number of oyster species (e.g. Shumway $\&$ Koehn 1982, Bougrier et al. 1995). Following these studies, we describe $\mathrm{VO}_{2}$ as an allometric function of temperature as:

$$
V \mathrm{O}_{2}=\alpha_{\mathrm{A}}+\alpha_{\mathrm{B}} \times T^{\mu}
$$

where $V \mathrm{O}_{2}$ is for a standard $1 \mathrm{~cm}$ oyster $\left(\mathrm{ml} \mathrm{O} \mathrm{O}_{2} \mathrm{~h}^{-1}\right.$ $\left.\mathrm{cm}^{-1}\right), T$ is water temperature $\left({ }^{\circ} \mathrm{C}\right), \alpha_{\mathrm{A}}\left(\mathrm{ml} \mathrm{O}_{2} \mathrm{~h}^{-1} \mathrm{~cm}^{-1}\right)$ is a constant, $\alpha_{\mathrm{B}}\left(\mathrm{ml} \mathrm{O}_{2} \mathrm{~h}^{-1} \mathrm{~cm}^{-1}{ }^{\circ} \mathrm{C}^{-\mu}\right)$ is a temperature coefficient, and $\mu$ is the temperature exponent.

Statistical analysis. The data were analysed using ANOVA to detect significant differences of CR calculated from: (1) chlorophyll versus particle concentrations and (2) high- versus low-condition oysters (using Systat 8: SPSS, Chicago, Illinois). Values of model parameters were estimated through regression analyses following standard least-squares procedures using S-plus $3.2^{\circledR}$ (StatSci, Seattle).

\section{RESULTS}

\section{Seston and organic content}

Seston concentration throughout the feeding experiments varied from 0.8 to $637 \mathrm{mg} \mathrm{l}^{-1}$ and organic matter ranged from 0.07 to $8.3 \mathrm{mg} \mathrm{l}^{-1}$. The organic content of the diets decreased exponentially from 71.9 to $0.7 \%$ with increasing seston concentration (Fig. 1).

\section{Morphometrics of Crassostrea gigas}

The relationships between volume, dry tissue weight and length in experiments were fitted by the following allometric functions:

$$
\begin{array}{ll}
V=\alpha \times L^{\rho} & \left(\mathrm{n}=52, \mathrm{R}^{2}=0.95\right) \\
\mathrm{DTW}=a \times L^{b} & \left(\mathrm{n}=52, \mathrm{R}^{2}=0.81\right)
\end{array}
$$

where $V$ is volume in $\mathrm{ml}, L$ is length in $\mathrm{cm}, \mathrm{DTW}$ is dry tissue weight in $\mathrm{g}, \alpha=0.38 \mathrm{ml} \mathrm{cm}^{-\rho}, \rho=2.15, a=4.1 \times$ $10^{-3} \mathrm{~g} \mathrm{~cm}^{-b}$ and $b=2.54$.

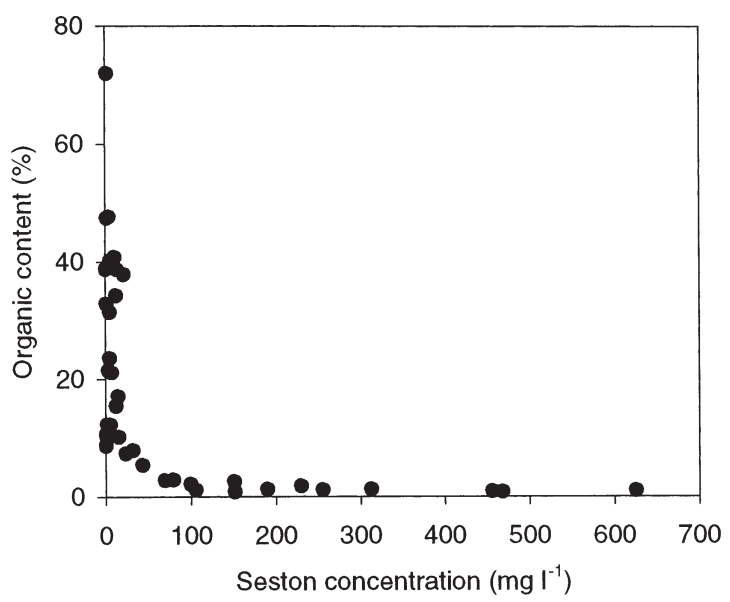

Fig. 1. Variation in organic content over range of seston concentrations used 


\section{Clearance rate}

There was no significant difference between CR calculated from the chlorophyll $a$ and total particle consumption ( $p>0.9, n=130)$, and hence either method can be used for estimation of the CR. The following results of CR were estimated from chlorophyll a consumption.

Influence of condition on CR. CR was measured for low- and high-condition oysters and standardised into both DTW and length. There was significant difference of CR standardised to DTW between low- and high-condition oysters $(\mathrm{p}<0.003, \mathrm{n}=60)$. However, CR standardised to length showed no significant difference between the 2 conditions $(p$ $>0.7, \mathrm{n}=60$ ). Therefore, we present all physiological measurements in terms of length in the following results.

Influence of body size on CR. CR was measured for a wide range of body sizes (19 to $145 \mathrm{~mm}$ ). The CR increased with increasing body size following the allometric equation:

$$
C R=\varphi \times L^{\theta} \quad\left(\mathrm{n}=180, \mathrm{R}^{2}=0.89\right)
$$

where $\varphi=0.16\left(\mathrm{l} \mathrm{h}^{-1} \mathrm{~cm}^{-\theta}\right)$ and $\theta=1.46$.

Influence of seston concentration on CR. The change of CR with $S$ is shown in Fig. 2. CR increased rapidly with increasing $S$ below $2 \mathrm{mg} \mathrm{l}^{-1}$ and then gradually reached a maximum level at an $S$ of about $10 \mathrm{mg} \mathrm{l}^{-1}$. Above this level, CR showed a pattern of consistent decline with increasing $S$ and no dramatic changes were observed.

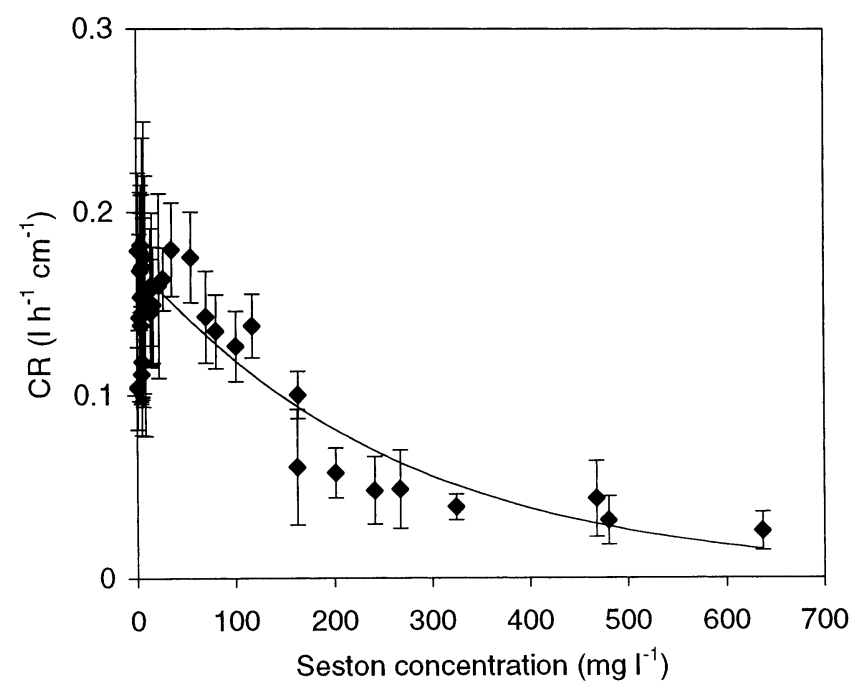

Fig. 2. Crassostrea gigas. Influence of seston concentration on clearance rate (CR). Data were standardised to an oyster of $1 \mathrm{~cm}$ body length $\left(\mathrm{l} \mathrm{h}^{-1} \mathrm{~cm}^{-1}\right)$ and are presented in terms of average $\mathrm{CR}( \pm \mathrm{SD})$
The function described in Eq. (1) was found to be a good fit to the data (Fig. 2). The best-fit values of model parameters obtained were: $\mathrm{CR}_{\max }=0.17 \mathrm{l} \mathrm{h}^{-1}$ $\mathrm{cm}^{-1} ; S_{\mathrm{HFC}}=0.39 \mathrm{mg} \mathrm{l}^{-1} ;$ and $k=3.78 \times 10^{-3}(\mathrm{n}=280$, $\mathrm{R}^{2}=0.79$ ).

Influence of temperature on CR. CR increased up to a temperature of $20.7^{\circ} \mathrm{C}$ and then decreased beyond this temperature (Fig. 3). Eq. (2) was fitted to the data and the best-fit parameter values were obtained as: $\mathrm{CR}_{\operatorname{maxl}}=0.24\left(\mathrm{l} \mathrm{h}^{-1} \mathrm{~cm}^{-1}\right), \beta=8.97 \times 10^{-4}\left(\mathrm{l} \mathrm{h}^{-1} \mathrm{~cm}^{-1}{ }^{\circ} \mathrm{C}^{-2}\right)$ and $T_{\mathrm{C}}=20.7^{\circ} \mathrm{C}\left(\mathrm{n}=280, \mathrm{R}^{2}=0.71\right)$.

\section{Filtration rate}

FR increased with increasing $S$ and no decline in FR was observed within the range of experimental $S$ (Fig. 4). It is well described by a Type 2 hyperbolic function of $S$ (Eq. 3). The best-fit parameters were estimated to be: $\mathrm{FR}_{\max }=16.5\left(\mathrm{mg} \mathrm{h}^{-1} \mathrm{~cm}^{-1}\right)$ and $S_{\mathrm{HFF}}=$ $51.5\left(\mathrm{mg} \mathrm{h}^{-1} \mathrm{~cm}^{-1}\right)\left(\mathrm{n}=280, \mathrm{R}^{2}=0.79\right)$.

\section{Ingestion rate}

IR is a function of food quantity, quality and selective ingestion on organic particles. IR data were fitted by Eq. (4). This was found to be a good fit and best-fit parameters were obtained as: $\mathrm{IR}_{\max }=5.8\left(\mathrm{mg} \mathrm{h}^{-1} \mathrm{~cm}^{-1}\right)$, $S_{\mathrm{HFI}}=64.1\left(\mathrm{mg} \mathrm{l}^{-1}\right), S_{\mathrm{HFS}}=3.7\left(\mathrm{mg} \mathrm{l}^{-1}\right)$. A comparison of predictions versus observed data is shown in Fig. 5 $\left(\mathrm{n}=280, \mathrm{R}^{2}=0.78\right)$.

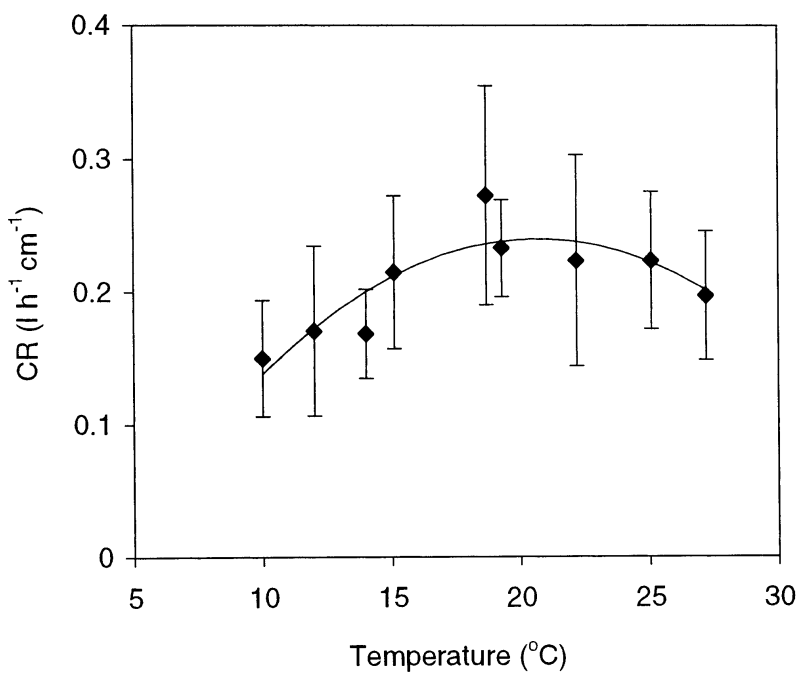

Fig. 3. Crassostrea gigas. Relationship between clearance rate (CR) and temperature. Data were standardised to an oyster of $1 \mathrm{~cm}$ body length $\left(\mathrm{h} \mathrm{h}^{-1} \mathrm{~cm}^{-1}\right)$ and are presented in terms of average $\mathrm{CR}( \pm \mathrm{SD})$ 


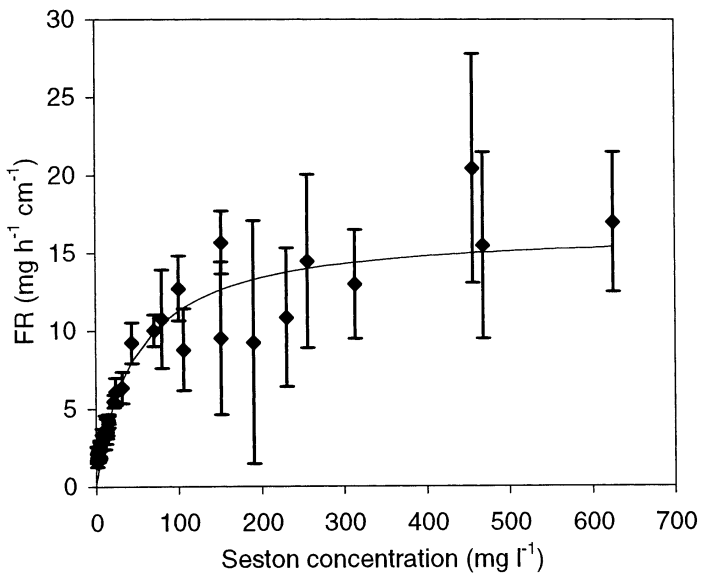

Fig. 4. Crassostrea gigas. Relationship between filtration rate (FR) and seston concentration. Data were standardised to an oyster of $1 \mathrm{~cm}$ body length $\left(\mathrm{mg} \mathrm{h}^{-1} \mathrm{~cm}^{-1}\right)$ and are presented in terms of average FR $( \pm \mathrm{SD})$

\section{Absorption efficiency}

AE was generally high throughout the experiments, but varied between 3 and 93\%. However, AE increased rapidly from low organic content of seston to a constant level of $86 \%$ above approximately $5 \%$ organic content (Fig. 6). The data were fitted by Eq. (5) and best-fit parameters were obtained as: $\mathrm{AE}_{\max }=$ $86 \%$ and $m=61.3\left(\mathrm{n}=280, \mathrm{R}^{2}=0.75\right)$.

\section{Oxygen consumption rates}

Influence of body size on $\boldsymbol{V O}_{2} \cdot V \mathrm{O}_{2}$ was measured over a range of sizes of oysters. As expected, the $V \mathrm{O}_{2}$ increased with increasing body size and can be well described by the allometric relationship:

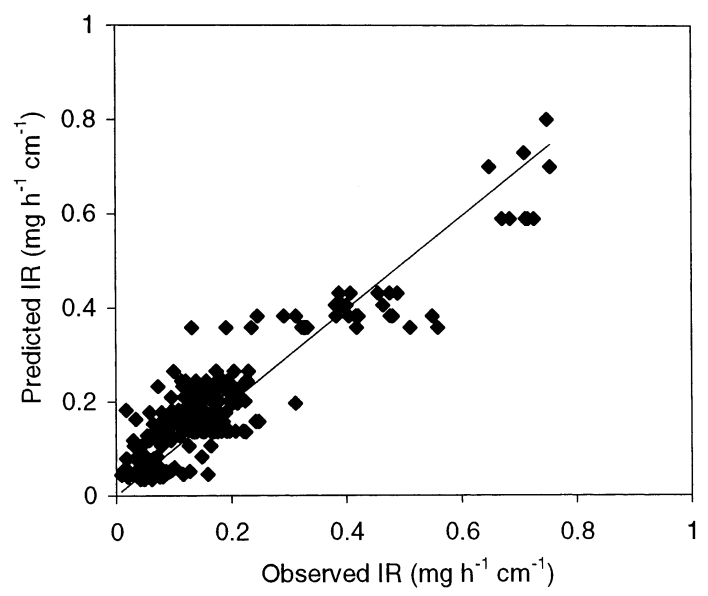

Fig. 5. Crassostrea gigas. Predicted and observed ingestion rates (IR). Line indicates where observations = predictions

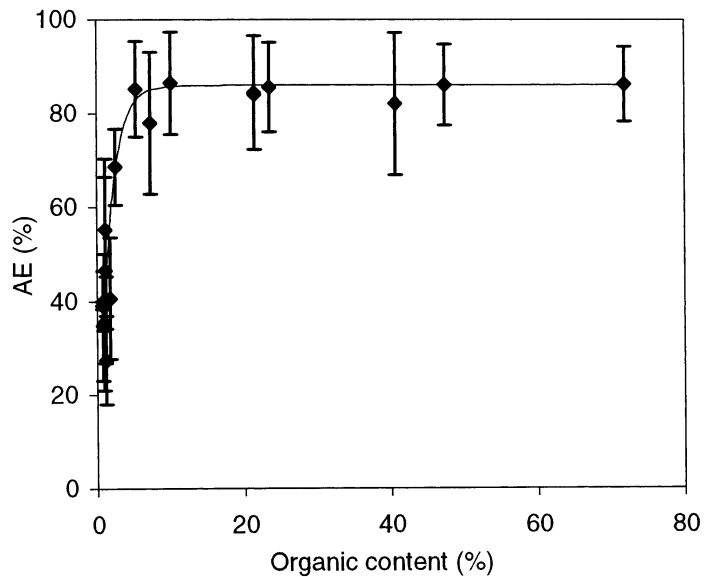

Fig. 6. Crassostrea gigas. Absorption efficiency (AE) in relation to organic content (\%) of seston. Means \pm SD

$$
V \mathrm{O}_{2}=e \times L^{\delta} \quad\left(\mathrm{n}=193, \mathrm{R}^{2}=0.91\right)
$$

where $V \mathrm{O}_{2}$ is oxygen consumption rate $\left(\mathrm{ml} \mathrm{O}_{2} \mathrm{~h}^{-1}\right), L$ is body length $(\mathrm{cm}), e=1.98 \times 10^{-3}\left(\mathrm{ml} \mathrm{O}_{2} \mathrm{~h}^{-1} \mathrm{~cm}^{-\delta}\right)$ and $\delta=2.36$.

Influence of temperature on $\boldsymbol{V O}_{2} \cdot V \mathrm{O}_{2}$ increased consistently with increasing temperature (Fig. 7). The respiration response of oysters to temperature is well described by Eq. (6), and best-fit parameters were obtained as follows: $\alpha_{\mathrm{A}}=1.73 \times 10^{-4}\left(\mathrm{ml} \mathrm{O}_{2} \mathrm{~h}^{-1} \mathrm{~cm}^{-1}\right)$, $\alpha_{\mathrm{B}}=3.09 \times 10^{-5}\left(\mathrm{ml} \mathrm{O}_{2} \mathrm{~h}^{-1} \mathrm{~cm}^{-1}{ }^{\circ} \mathrm{C}^{-\mu}\right)$ and $\mu=1.44$ (n=532, $\left.\mathrm{R}^{2}=0.93\right)$.

\section{DISCUSSION}

Dynamic energy budget (DEB) models are a necessary component of oyster carrying capacity studies because of the need to quantify the feedback between

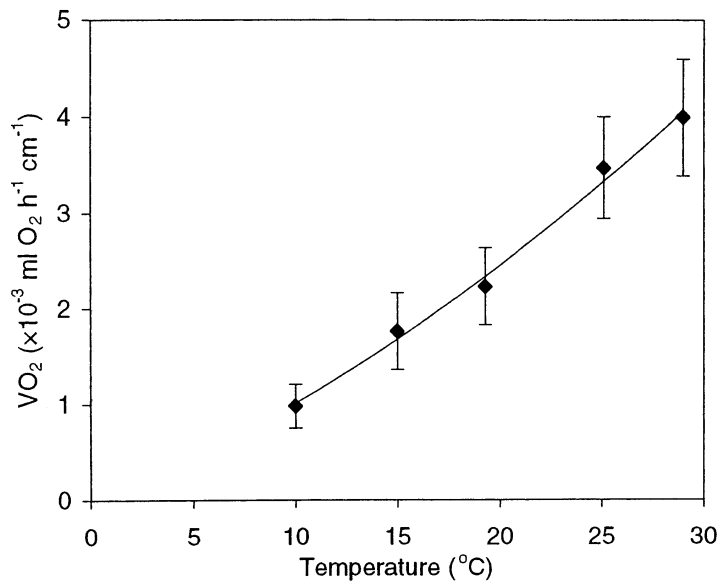

Fig. 7. Crassostrea gigas. Relationship between oxygen consumption rate $\left(V_{2}\right)$ and temperature. Means \pm SD 
oyster feeding and the food supply. An important stage in the development of a DEB model is to determine the functions and parameters that describe individual processes such as filtration and ingestion. In this paper we have made the first attempt to describe such relationships for the range of environmental conditions experienced by a population of farmed oysters Crassostrea gigas, in the Marlborough Sounds, New Zealand.

In our study, physiological rates were standardised to body length. This is contrary to most previous studies on bivalve molluscs, which use dry tissue weight (DTW) as a measure of size (e.g. Bayne \& Newell 1983, Bougrier et al. 1995, Barillé et al. 1997). Our data show that there was a high DTW-specific clearance rate (CR), whilst length-specific CR was not significant. This variation in CR was mainly caused by oyster condition, which changes with the environment, for instance with food availability. This is in agreement with a number of studies on bivalves (e.g. Iglesias et al. 1996, Labarta et al. 1997). DTW consists of structural material and storage. Variation in animal condition is a consequence of increase or decrease in storage. It has been argued that storage is an accumulation of energy reserves from assimilation that are readily available for reproduction and maintenance but hardly participate in respiration and ingestion (e.g. Horstmann 1958, DeMott 1982, Porter et al. 1982, Kooijman 1986, van Haren \& Kooijman 1993, Nisbet et al. 1996). By studying the pond snail Lymnaea stagnalis, Horstmann (1958) further argued that a freshly produced egg consists of a relatively large amount of energy reserves and an infinitesimally small amount of structural body mass, but hardly respires. All these studies suggest that structural material rather than storage is the main, if not the only, substance involved in physiological activity.

The above variation in CR disappeared when standardised to length, because length is more closely related to structural biomass (Ren et al. unpubl. data). There is considerable evidence that the effect of body size on CR is primarily determined by the branchial area (Hughes 1969, Møhlenberg \& Riisgård 1979). A close relationship between gill area and shell height has been found in Pinctada margaritifera, and CR was found to increase isometrically with gill size (Pouvreau et al. 1999). In our study, because of a lack of information on gill area, length was used as a measure of body size in the clearance function. We have used length rather than the more traditional DTW, because, a priori, our expectation is that there will be considerably more variability in the relationship between DTW and gill area between experiments (although not necessarily in any one experiment) as opposed to the relationship between length and gill area. This hypothesis, however, needs to be examined.
The disadvantage in using length to represent body size is that it conveys no information on the physiological state of the oyster during the experiment. It is possible, perhaps even likely, that the physiological state, e.g. during starvation conditions, may have a significant effect on physiological rates such as the CR. However, any effect is likely to depend on the degree of reserves in a non-simplistic way, and is unlikely to be adequately represented by the simple addition of 'structural' plus 'reserve' tissues as implied by the use of total DTW (in the relationship between rates and body size). The separation of the effects of structural and reserve tissue contributions to the rate processes needs to be determined by a set of carefully controlled experiments in which the physiological condition of genetically similar stock is varied.

The value of the exponent in the relationship between CR and shell length in our experiment was 1.46, and between CR and DTW was 0.57. Over many previous studies, considerable variability has been observed in both inter- and intra-specific variability in the value of $b$ (DTW) - typically within the range 0.4 to 0.8 (see Bayne \& Newell 1983). To our knowledge, the range of the $b$ value (DTW) for Crassostrea gigas was 0.44 to 0.73 in some previous studies, e.g. 0.44 (Bougrier et al. 1995), 0.61 on average (Walne 1972) and 0.73 (Gerdes 1983a). Although the $b$ value from our measurements was slightly lower than that found for some other bivalve studies, it is within the typical range.

Many authors (e.g. Percy et al. 1971, Bougrier et al. 1995) have reported seasonal variation in oxygen consumption rates $\left(V \mathrm{O}_{2}\right)$ in marine bivalves. $V \mathrm{O}_{2}$ in Mytilus edulis was higher in winter and spring and lower in summer (Bruce 1926, Krüger 1960, Bayne et al. 1973). Bruce (1926) and Krüger (1960) found that this seasonal variation in $V \mathrm{O}_{2}$ correlated with the gametogenic cycle of the mussels, indicating that gametogenesis involved a high $V \mathrm{O}_{2}$. Production of reserve material requires little energy and, therefore, leads to lower metabolic rates in terms of DTW.

However, $\mathrm{VO}_{2}$ involves a complex interaction between gametogenesis and DTW. Gerdes (1983b) observed that the $\mathrm{VO}_{2}$ of Crassostrea gigas was lower during the resting stage of gametogenesis in winter than during the active stage in summer, suggesting that gonad development needs additional energy. This is in agreement with the energy used during gametogenesis by the scallop Argopecten irradians concentricus observed by Barber \& Blake (1981). These authors found that the decline in adductor muscle protein is greater than can be accounted for solely in terms of gonad development, and concluded that the lost energy is likely used to meet maintenance requirements during the later stages of oogenesis and spawning. The reserve material and gametogenesis would contribute to the variation in 
the relationship between physiological rates and DTW. Studies on energy requirement of gametogenesis would help understand the variation in $V_{2}$.

Our measurements of the temperature effect on CR and $V \mathrm{O}_{2}$ displayed a similar trend to those of Bougrier et al. (1995). $V \mathrm{O}_{2}$ increased with temperature over the range of experimental temperatures. CR increased with increasing temperature up to a maximum of $20.7^{\circ} \mathrm{C}$, and then declined with a further increase in temperature. This optimal temperature estimated for $\mathrm{CR}$ in our study was $1.7^{\circ} \mathrm{C}$ higher than that $\left(19^{\circ} \mathrm{C}\right)$ found by Bougrier et al. (1995). Various $V_{2}$ have been reported for Crassostrea gigas. Gerdes (1983b) found that $V \mathrm{O}_{2}$ was $0.65 \mathrm{ml} \mathrm{O}_{2} \mathrm{~h}^{-1} \mathrm{~g}^{-1}$ at $20^{\circ} \mathrm{C}$, while Bougrier et al. (1995) recorded $0.96 \mathrm{ml} \mathrm{O}_{2} \mathrm{~h}^{-1} \mathrm{~g}^{-1}$ at the same temperature. Our measurement was $0.0025 \mathrm{ml} \mathrm{O}_{2} \mathrm{~h}^{-1}$ $\mathrm{cm}^{-1}$, or $0.41 \mathrm{ml} \mathrm{O}_{2} \mathrm{~h}^{-1} \mathrm{~g}^{-1}$ when converted to the same unit using the length-DTW relationship. Considerable variability in physiological energetic parameters has been recorded in many other studies of marine bivalves as well (e.g. Foltz et al. 1983, Volchaert \& Zouros 1989). This large variation in $V \mathrm{O}_{2}$ is possibly again due to differences in the condition of experimental oysters, and/or the genetic differences among populations. Further studies on different populations in similar condition are necessary.

The CR of marine bivalves has usually been estimated from particle consumption. It is a consequence of an interaction between pumping rate of water and the extraction efficiency of particles from the water. We postulated that pumping rate declines with increasing seston concentration $(S)$ so that the flux of particles through the filtering apparatus saturates. Hence, we have assumed that the extraction rate remains constant as $S$ increases (for $S$ much greater than the half-saturation coefficient, $S_{\mathrm{HFC}}$ ). This assumption is similar to the postulation of Winter (1978) that decline in the CR of Mytilus edulis is a consequence of regulation of the pumping rate in response to increasing $S$. In this study, the lack of a decline in the filtration rate (FR; Fig. 4) supports the view that the pumping rate is being regulated in response to increasing $S$.

Hence, although our study is generally in agreement with that of Barillé \& Prou (1993) at high $S$, no sharp decrease in $\mathrm{CR}$ was observed within the range of our experimental concentrations, as observed by Barillé \& Prou. Furthermore, the rate of decrease in CR was lower in our study, particularly at high $S$. For example, the CR measured by Barillé \& Prou was $0.05 \mathrm{l} \mathrm{h}^{-1} \mathrm{~g}^{-1}$ at about $250 \mathrm{mg} \mathrm{l}^{-1}$, which is much lower than that estimated in this study $\left(0.074 \mathrm{l} \mathrm{h}^{-1} \mathrm{~cm}^{-1}\right.$ or $1.72 \mathrm{l} \mathrm{h}^{-1} \mathrm{~g}^{-1}$ at the same $S$ ). These differences may have arisen for reasons similar to those causing variation in $\mathrm{CR}$ and $V \mathrm{O}_{2}$ as discussed above. In addition, different experimental diets may have played a role.
We exposed oysters to a wide range of $S$ and organic concentrations with organic content decreasing with increasing $S$. This reflects conditions in the natural marine environment, where re-suspension of sediments results in decreasing organic content with increasing $S$ (e.g. Widdows et al. 1979, Navarro \& Iglesias 1993). The relationship between FR and $S$ was found to be reasonably well described by a simple Type 2 hyperbolic function within the range of $S$ tested.

Some previous studies have found that FR in Crassostrea gigas declines with increasing $S$ (Deslous-Paoli et al. 1987, Barillé et al. 1997). In those studies, FR increased with increasing $S$ up to about $100 \mathrm{mg} \mathrm{l}^{-1}$ and thereafter drastically decreased to a very low level at $S$ above $200 \mathrm{mg} \mathrm{l}^{-1}$. The authors attributed this decrease of FR to an abrupt reduction in CR. FR has also been reported to decline at high $S$ in other species. Navarro \& Widdows (1997), for example, found a decline in FR above $300 \mathrm{mg} \mathrm{l}^{-1}$ for the cockle Cerastoderma edule, and Hawkins et al. (1999) observed a decline in FR over $1000 \mathrm{mg} \mathrm{l}^{-1}$ in the mussel Perna canaliculus. We did not see this decline of FR for $C$. gigas within the range of $S$ tested, which suggests that the $S$ above which FR declines is likely to be above $600 \mathrm{mg} \mathrm{l}^{-1}$ for the population of $C$. gigas in New Zealand.

We have assumed that the ability of the oyster to sort organic and inorganic particulates saturates with increasing $S$. We have also assumed that the total flux of material passing through the filtering apparatus saturates (see above). For these assumptions to be consistent, the sorting term must saturate at a lower $S$, i.e. the half-saturation coefficient for the sorting term $\left(S_{\mathrm{HFS}}\right)$ must be smaller than the half-saturation coefficient for the filtration term $\left(S_{\mathrm{HFI}}\right)$. Indeed, $S_{\mathrm{HFI}}$ was found to be 17 -fold greater than $S_{\mathrm{HFS}}$ in the least-squares best-fit procedure, which supports our assumption that particle sorting for organic content is a significant factor in ingestion rate.

Absorption efficiency (AE) increased with increasing organic content of the seston. This trend is similar to the findings of Barrillé et al. (1997); however, the AE was higher and the rate of increase with organic content was greater in the present study. This is possibly a consequence of different food composition, since in our experimental diet phytoplankton contributed a significant fraction of organic matter, reflecting the environment in the Marlborough Sounds (James \& Ross 1996, Ross \& James unpubl. data); in contrast, the organic fraction was predominantly detrital in MarennesOléron Bay (e.g. Goulletquer 1989, Raillard et al. 1993). Oysters tend to respond differently to phytoplankton and detritus during the digestive process. Many authors (e.g. Williams 1981, Crosby et al. 1989, Klepper et al. 1994, Campbell \& Newell 1998) observed higher $\mathrm{AE}$ on phytoplankton than on detritus in 
bivalves. Selective digestion for phytoplankton over detritus probably caused this difference in AE measured in different environments.

In this study, we have measured the physiological rates of Crassostrea gigas under a wide range of environmental conditions (temperature, food quantity and quality). A set of physiological models reflecting mechanisms of oyster physiology have been constructed to provide important functions and parameters for DEB models. This study not only contributes to the knowledge of the physiology of this species but it also facilitates further studies on carrying-capacity models.

Acknowledgements. This study was supported by a University of Canterbury scholarship to J.S.R. and by logistic support from NIWA. The authors would like to thank Clive HowardWilliams and Mark James for supporting the study, and for reviewing this manuscript. We would like to thank Jack van Berkel, Eric Koops and Mark Weatherhead for providing logistic support throughout the experiment and Sealord Shellfish Ltd for providing oyster samples. We are also grateful to 3 anonymous reviewers for their criticisms of this manuscript.

\section{LITERATURE CITED}

Barber BJ, Blake NJ (1981) Energy storage and utilization in relation to gametogenesis in Argopecten irradians concentricus (Say). J Exp Mar Biol Ecol 42:121-134

Barillé L, Prou J (1993) Modeling Japanese oyster physiological processes under natural tidal variation in suspended particulate matter. ICES Comm Meet (Shellfish Comm) 1992/F:1-12

Barillé L, Bougrier S, Geairon P, Robert JM (1994) Experimental feeding of oyster Crassostrea gigas with three populations of different-sized modes of diatom Haslea ostrearia (Simonsen). Oceanol Acta 17:201-210

Barillé L, Prou J, Héral M, Razet D (1997) Effects of high natural seston concentrations on the feeding, selection and absorption of the oyster Crassostrea gigas (Thunberg). J Exp Mar Biol Ecol 212:149-172

Bayne BL, Hawkins AJS (1990) Filter-feeding in bivalve mollluscs: controls on energy balance. Comparative physiology, animal nutrition and transport processes. Comp Physiol 5:70-93

Bayne BL, Newell RC (1983) Physiological energetics of marine molluscs. In: Saleuddin ASM, Wilbur KM (eds) The Mollusca, Vol 4. Physiology. Part 1. Academic Press, New York, p 407-515

Bayne BL, Thompson RJ, Widdows J (1973) Some effects of temperature and food on the rate of oxygen consumption by Mytilus edulis L. In: Wieser W (ed) Effects of temperature on ectothermic organisms. Springer-Verlag, Berlin, p 181-193

Bayne BL, Hawkins AJS, Navarro E (1987) Feeding and digestion by the mussel Mytilus edulis L. (Bivalvia, Mollusca) in mixtures of silt and algal cells at low concentration. J Exp Mar Biol Ecol 111:1-22

Bougrier S, Geairon P, Deslous-Paoli JM, Bacher C, Jonquiéres G (1995) Allometric relationships and effects of temperature on clearance and oxygen consumption rates of Crassosrea gigas (Thunberg). Aquaculture 134:143-154

Bricelj VM, Malouf RE (1984) Influence of algal and suspended sediment concentrations on the feeding physio- logy of the hard clam Mercenaria mercenaria. Mar Biol 84: 155-165

Bruce JR (1926) The respiratory exchange of the mussel (Mytilus edulis L.). Biochem J 20:829-845

Campbell DE, Newell CR (1998) MUSMOD, a production model for bottom culture of the blue mussel, Mytilus edulis L. J Exp Mar Biol Ecol 219:171-203

Crisp DJ, Yule AB, White KN (1985) Feeding by oyster larvae: the functional response, energy budget and a comparison with mussel larvae. J Mar Biol Assoc UK 65:759-783

Crosby MP, Langdon CJ, Newell RIE (1989) Importance of refractory plant material to the carbon budget of the oyster Crassostrea virginica. Mar Biol 100:343-352

DeMott WM (1982) Feeding selectivities and relative ingestion rates of Daphnia and Bosmina. Limnol Oceanogr 27: 518-527

Deslous-Paoli JM, Héral M, Boromthanarat W, Razet D, Garnier J, Prou J, Barillé L (1987) Evolution saisonnière de la filtration de bivalves intertidaux dans des conditions naturelles. Océanis 13:575-579

Deslous-Paoli JM, Lannou AM, Geairon P, Bougrier S, Raillard O, Héral M (1992) Effects of the feeding behaviour of Crassostrea gigas (bivalve molluscs) on biosedimentation of natural particulate matter. Hydrobiologia 231: 85-91

Dinamani P (1971) Occurrence of the Japanese oyster, Crassostrea gigas (Thunberg) in the Northland, New Zealand. NZ J Mar Freshw Res 5:352-357

Dinamani P (1987) Gametogenic patterns in populations of Pacific oyster, Crassostrea gigas, in Northland, New Zealand. Aquaculture 64:65-76

Epifanio CE, Edwart J (1977) Maximum ration of four algal diets for the oyster Crassostrea virginica Gmelin. Aquaculture 33:13-29

Foltz DW, Newkirk GF, Zouros E (1983) Genetics of growth rate in the American oyster: absence of interactions among enzyme loci. Aquaculture 33:157-165

Foster-Smith RL (1975) The effect of concentration of suspension on the filtration rates and pseudofaecal production for Mytilus edulis (L.), Cerastoderma edulis (L.), and Venerupis pallustra (Montague). J Exp Mar Biol Ecol 17:1-22

Gerdes D (1983a) The Pacific oyster Crassostrea gigas. Part I. feeding behaviour of larvae and adults. Aquaculture 31: $195-219$

Gerdes D (1983b) The Pacific oyster Crassostrea gigas. Part II. Oxygen consumption of larvae and adults. Aquaculture 31:221-231

Gibbs MM, Vant WN (1997) Seasonal changes in factors controlling phytoplankton growth in Beatrix Bay, New Zealand. NZ J Mar Freshw Res 31: 237-248

Goulletquer P (1989) Etude des facteurs environnementaux intervenant sur la production de la palourde d'élevage Ruditapes philippinarum. Université de Bretagne Occidentale, Brest

Hawkins AJS, James MR, Hickman RW, Hatton S, Weatherhead M (1999) Modelling of suspension-feeding and growth in the green-lipped mussel Perna canaliculus exposed to natural and experimental variations of seston availability in the Marlborough Sounds, New Zealand. Mar Ecol Prog Ser 191:217-232

Héral M (1993) Why carrying capacity models are useful tools for management of bivalve molluscs culture. In: Dame RF (ed) Bivalve filter feeders in estuarine and coastal ecosystem processes. Springer-Verlag, Berlin, p 455-477

Héral M, Deslou-Paoli JM (1991) Oyster culture in European countries. In: Menzel W (ed) Estuarine and marine bivalve mollusk culture. CRC Press, Boca Raton, p 153-190 
Héral M, Drinkwaard AC (1990) Management of oyster and mussel culture. In: de Pauw N, Billard R (eds) Aquaculture Europe '89. Business joins science. European Aquaculture Society, Bredene 12:147-162

Horstmann HJ (1958) Sauerstoffverbrauch und Trockengewicht der Embryonen von Lymnaea stagnalis L. Z Vergl Physiol 41:390-404

Hughes RN (1969) A study of feeding in Scrobicularia plana. J Mar Biol Assoc UK 49:805-823

Iglesias JIP, Navarro E, Jorna PA, Aementia I (1992) Feeding, particle selection and absorption in cockles Cerastoderma edule (L.) exposed to variable conditions of food concentration and quality. J Exp Mar Biol Ecol 162:177-198

Iglesias JIP, Pérez-Camacho A, Navarro E, Labarta U, Beiras R, Hawkins AJS, Widdows J (1996) Microgeographic variability in feeding, absorption and condition of mussels (Mytilus galloprovincialis Lmk): a transplant experiment. J Shellfish Res 15:673-680

James MR, Ross AH (1996) How many mussels can we farm? Seafd NZ 4:50-53

Klepper O, van der Tol MWM, Scholten H, Herman PMJ (1994) SMOES: a simulation model for the Oosterschelde ecosystem. Part I: description and uncertainty analysis. Hydrobiologia 282/283:437-451

Kooijman SALM (1986) What the hen can tell about her eggs: egg development on the basis of energy budgets. J Math Biol 23:163-185

Krüger F (1960) Zur Frage der Grössenabhängigkeit des Sauerstoffverbrauches von Mytilus edulis L. Helgol Wiss Meeresunters 7:125-148

Labarta U, Fernandez-Reiriz MJ, Babarro JMF (1997) Differences in physiological energetics between intertidal and raft cultivated mussels Mytilus galloprovincialis. Mar Ecol Prog Ser 152:167-173

Le Gall JL, Raillard O (1988) Influence of temperature on the physiology of the oyster Crassostrea gigas. Océanis 14: 603-608

Møhlenberg F, Riisgård HU (1979) Filtration rate, using a new indirect technique, in thirteen species of suspensionfeeding bivalves. Mar Biol 54:143-147

Navarro E, Iglesias JIP (1993) Infaunal filter-feeding bivalves and the physiological response to short-term fluctuations in food availability and composition. In: Dame RF (ed) Bivalve filter feeders in estuarine and coastal ecosystem processes. Springer-Verlag, Berlin, p 25-56

Navarro JM, Widdows J (1997) Feeding physiology of Cerastoderma edulis in response to a wide range of seston concentrations. Mar Ecol Prog Ser 152:175-186

Neudecker TH (1981) Sex determination and maturation of the Pacific oyster (Crassostrea gigas) off the German coast. Spec Publ Eur Maricult Soc 6:249-254

Editorial responsibility: Otto Kinne (Editor),

Oldendorf/Luhe, Germany
Nisbet RM, Ross AH, Brooks AJ (1996) Empirically-based dynamic energy budget models: theory and an application to ecotoxicology. Nonlin Wld 3:85-106

Percy JA, Aldrich FA, Marcus TR (1971) Influence of environmental factors on respiration of excised tissue of American oysters, Crassostrea virginica (Gmelin). Can J Zool 49: 353-360

Porter KG, Gerritsen J, Orcutt JD Jr (1982) The effect of food concentration on swimming patterns, feeding behaviour, ingestion, assimilation, and respiration by Daphnia. Limnol Oceanogr 27:935-949

Pouvreau S, Jonquières G, Buestel D (1999) Filtration by the pearl oyster, Pinctada margaritifera, under conditions of low seston load and small particle size in a tropical lagoon habitat. Aquaculture 176:295-314

Prince J (1995) Limited effects of the sea urchin Echinometra mathaei (de Blainville) on the recruitment of benthic algae and macroinvertebrates into intertidal rock platforms at Rottnest Island, Western Australia. J Exp Mar Biol Ecol 186:237-258

Raillard O, Deslous-Paoli JM, Héral M, Razet D (1993) Modelling growth and feeding of the Japanese oyster Crassostrea gigas in Marennes-Oléron Bay (France). Oceanol Acta 16:73-82

Shumway TM, Koehn RK (1982) Oxygen consumption in the American oyster Crassostrea virginica. Mar Ecol Prog Ser 9:59-68

Strickland JDH, Parson TR (1968) A practical handbook of seawater analysis. Bull Fish Res Board Can 167:1-311

Thompson RJ, Bayne BL (1974) Some relationships between growth, metabolism and food in the mussel Mytilus edulis. Mar Biol 27:317-326

van Haren RJF, Kooijman SALM (1993) Application of a dynamic energy budget model to Mytilus edulis (L.). Neth J Sea Res 31:119-133

Volckaert F, Zouros E (1989) Allozyme and physiological variation in the scallop Placopecten magellanicus and a general model for the effects of heterozygosity on fitness in marine molluscs. Mar Biol 103:51-61

Walne PR (1972) The influence of current speed, body size and water temperature on the filtration rate of five species of bivalves. J Mar Biol Assoc UK 52:345-374

Widdows J, Fieth P, Worrall CM (1979) Relationships between seston, available food and feeding activity in the common mussel Mytilus edulis. Mar Biol 50:195-207

Williams P (1981) Detritus utilization by Mytilus edulis. Estuar Coast Shelf Sci 12:739-746

Winter JE (1978) A review on the knowledge of suspension-feeding in lamellibranchiate bivalves, with special reference to artificial aquaculture systems. Aquaculture 13:1-33

Submitted: June 28, 1999; Accepted: May 25, 2000 Proofs received from author(s): November 15, 2000 